Ann. Biol. anim. Bioch. Biophys., 1977, 17 (5 A), 759-764.

\title{
Influence of some chemical modifications on the steroidogenic activity of luteinizing hormone (LH)
}

par C. HERMIER, Marion EVRARD, P. DE LA LLOSA

Laboratoire des Hormones Polypeptidiques

CNRS, 91190 Gif-sur-Yrette, France.

Summary. We report the infivence of different chemical modifications of luteinizing hormone (LH) lysine residues on progesterone synthesis, induced in vitro by this hormone, in the pseudo-pregnant rat ovary :

- Carbamylation of half of the lysines, with abolition of the positive charges, sufficed to suppress 90 p. 100 of LH biological activity,

- Guanidination of 65 p. 100 of the lysines caused a 55 p. 100 loss of the activity,

- Methylation of 75 p. 100 of the lysines did not modify the biological potency of the hormone.

The influence of some chemical modifications of the lysine residues of luteinizing hormone (LH) was studied recently in our laboratory (De La Llosa et al., 1974) by means of the ovarian ascorbic acid depletion test (Parlow, 1961) : this in vivo bioassay is very sensitive to any changes in the clearance rate of the hormone produced by the chemical modifications. We therefore thought that it would be interesting to examine the biological potencies of these derivatives using in vitro bioassays. The in vitro biosynthesis of progesterone by pseudopregnant rat ovaries can be employed to measure the potency of LH (Hermier and Jutisz, 1968 ; Watson 1971). In this method, a global response of in vitro steroidogenesis to stimulation by $\mathrm{LH}$ is obtained, proportional to the $\mathrm{LH}$ concentration. In the present work, we have tested several LH derivatives. One of them (methylated LH) is of particular interest because it is employed in our laboratory as a labelled ligand in the study of LH binding to receptors (De la Llosa-Hermier et al., 1976).

\section{Materials and methods.}

Highly purified ovine LH was obtained in our laboratory (Justisz and Courte, 1968). The relative potency was $2 \times \mathrm{LH}-\mathrm{NIH}-\mathrm{SI}$. Derivatives of LH (methylated, carbamylated and guanidinated $\mathrm{LH}$ ) were prepared as previously reported. The degree of chemical modifications was defermined by aminoacid analysis (De la Llosa ef al., 1974). The relative potencies of the derivatives in the Parlow test are : 1.43 for the 
methylated LH (75 p. 100 modified lysine), 0.55 for the guanidinated LH (65 p. 100 lysine modified), and 0.06 for the carbamylated LH (53 p. 100 modified lysine), in terms of native luteinizing hormone (De La Llosa ef al., 1974).

Pseudopregnant rat ovaries were obtained by treatment with PMSG (50 UI/rat at 28 days) and HCG (50 Ul/rat at 31 days). The rats were killed at 37 days. The ovaries were removed, minced, and pre-incubated 15 minutes in Krebs-Ringer medium ( $\mathrm{pH}$ 7.4), containing 0.1 p. 100 bovine serum albumin and saturated by $\mathrm{O}_{2}+\mathrm{CO}_{2}$ (93: 7 p. 100). The incubation was performed under constant conditions for $3 \mathrm{hrs}$ ( $1 \mathrm{~g}$ of wet ovaries $/ 10 \mathrm{ml}$ of medium). After incubation, the ovaries were homogenized in the medium and the progesterone concentrations were determined by extractions with diethyl ether, chloroform (4.1) followed by thin layer chromatography (Merck Silica Sel G) and spectrophotometric analysis. Small amounts of progesterone ${ }^{14} \mathrm{C}-4$ were added to enable correction of the losses of the steroid during extraction and purification (Hermier and Justisz, 1968).

\section{Results.}

Steroidogenic activity of methylated $\mathrm{LH}$.

Stimulation by methylated LH and native LH of progesterone production in incubated slices of pseudopregnant rat ovaries gave dose response curves between $4 \times 10^{-10} \mathrm{M}$ and $5 \times 10^{-9} \mathrm{M}$ as shown in figure 1 . The maximal activation is not different for the native or the methylated $\mathrm{LH}$.

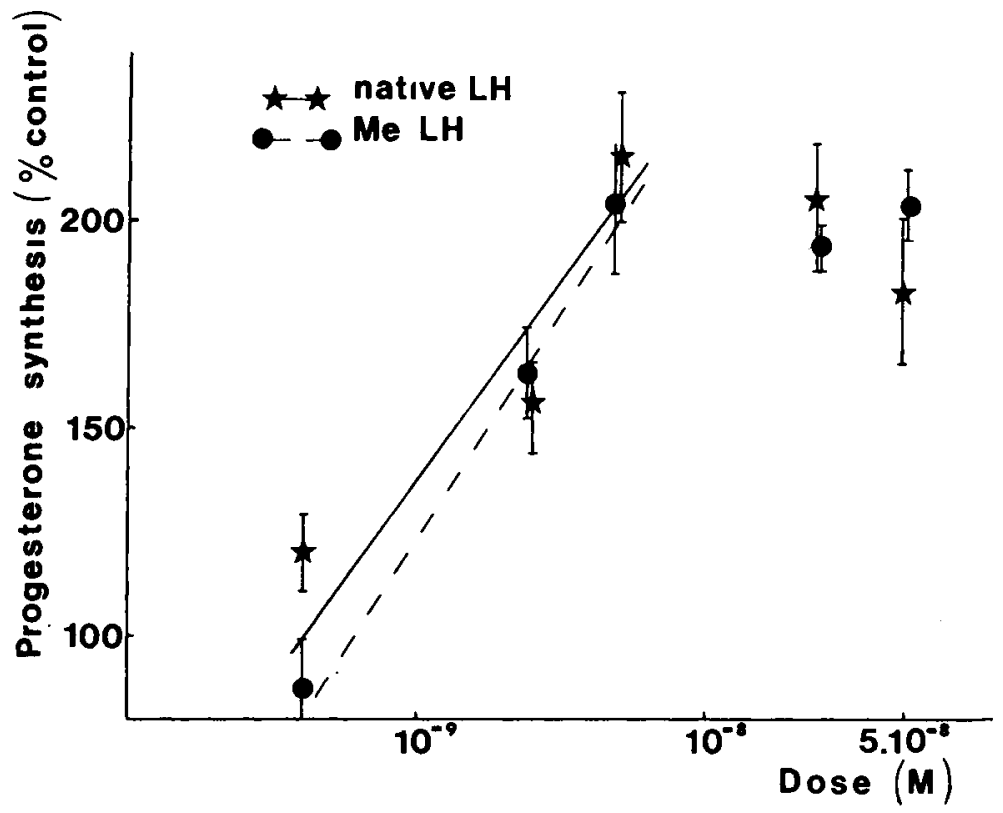

FIG. 1. - Progesterone biosynthesis, by pseudopregnant rat ovaries, in vitro, during incubation for 3 hrs, induced by native $\mathrm{LH}$ or methylated $\mathrm{LH}$. Each point shows the mean \pm confidence limits, $p .<0.05$ (1 incubation). Progesterone control : $69.08 \pm 4.91 \mu \mathrm{g} / \mathrm{g}$. 
The relative potency expressed in terms of native $\mathrm{LH}$ and calculated by comparison of two doses of standard LH and two doses of methylated LH is shown in table 1. The potencies of methylated LH and native LH are not significantly different.

\section{TABLE 1}

Steroidogenic activity of three derivatives of luteinizing hormone (LH)

\begin{tabular}{lc}
\hline Derivatives & $\begin{array}{c}\text { Relative potencies } \\
\text { in terms of native luteinizing hormone } \\
\text { with } 95 \text { p. } 100 \text { confidence limits }\end{array}$ \\
\hline Methylated & $1.00(0.88-1.14)$ \\
Guanidinated & $0.73(0.54-1.00)$ \\
& $0.51(0.39-0.67)$ \\
Carbamylated & $0.38(0.32-0.45)$ \\
& $0.15(0.05-0.43)$ \\
& $0.055(0.04-0.07)$
\end{tabular}

Two bioassays are performed for each derivative. The relative potencies are calculated by comparison between the responses (biosynthesis of progesterone in vifro) induced by two different doses of $\mathrm{LH}$ and by two doses of $\mathrm{LH}$ derivatives, in the same ratio.

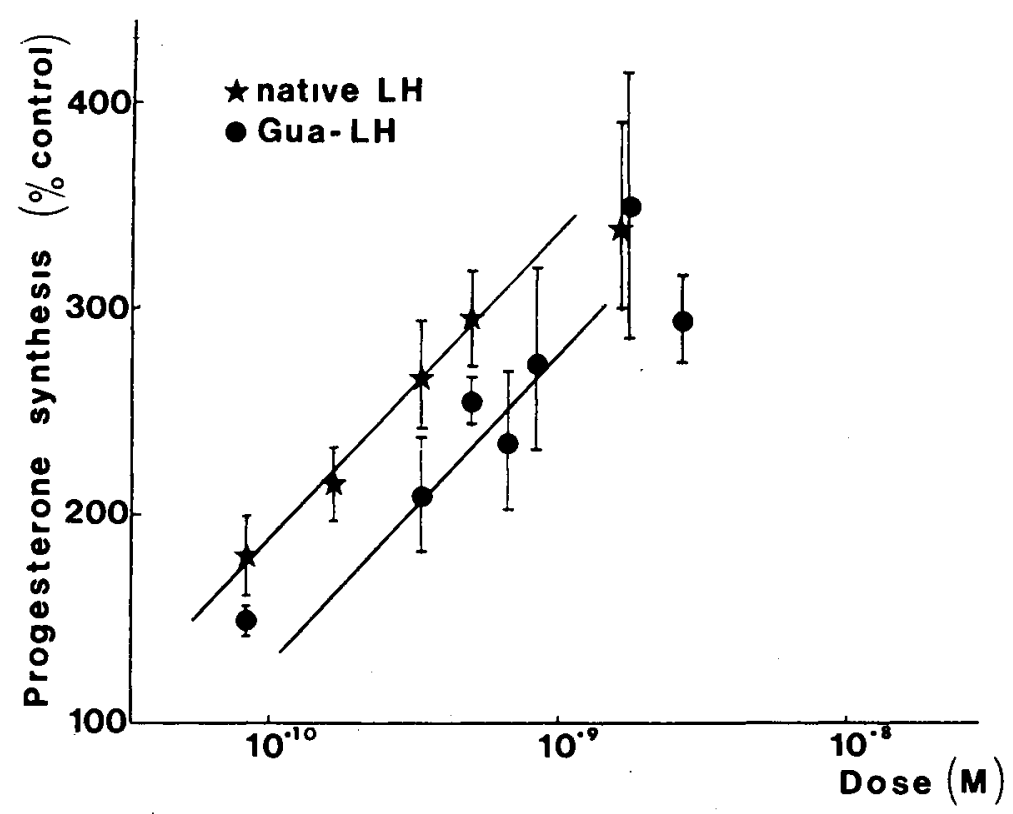

FIG. 2. - Progesterone biosynthesis by pseudopregnant raf ovaries, in vitro, during incubation for 3 hrs, induced by native $L H$ or guanidinated $L H$. Each point shows the mean $\pm S E M$ ( 3 incubations). Progesterone control : $35.69 \pm 3.83 \mu \mathrm{g} / \mathrm{g}$. 
Steroidogenic activity of guanidinated $L H$.

Fig. 2 shows the stimulation by guanidinated $\mathrm{LH}$ and by native LH of progesterone production, in slices of pseudopregnant rat ovaries incubated for three hours. No differences are observed between the maximal activation produced by the two hormones (native and modified).

A marked decrease of biological activity is observed as a consequence of this modification (table 1). The residual activity is about 45 p. 100 .

Steroidogenic activity of carbamylated $L H$.

The stimulation by carbamylated LH (53 p. 100 of modified lysine) and native LH, of progesterone biosynthesis in incubated slices of pseudopregnant rat ovaries is shown in figure 3. The maximal stimulation attained by untreated $\mathrm{LH}$ and carbamylated $\mathrm{LH}$ is similar.

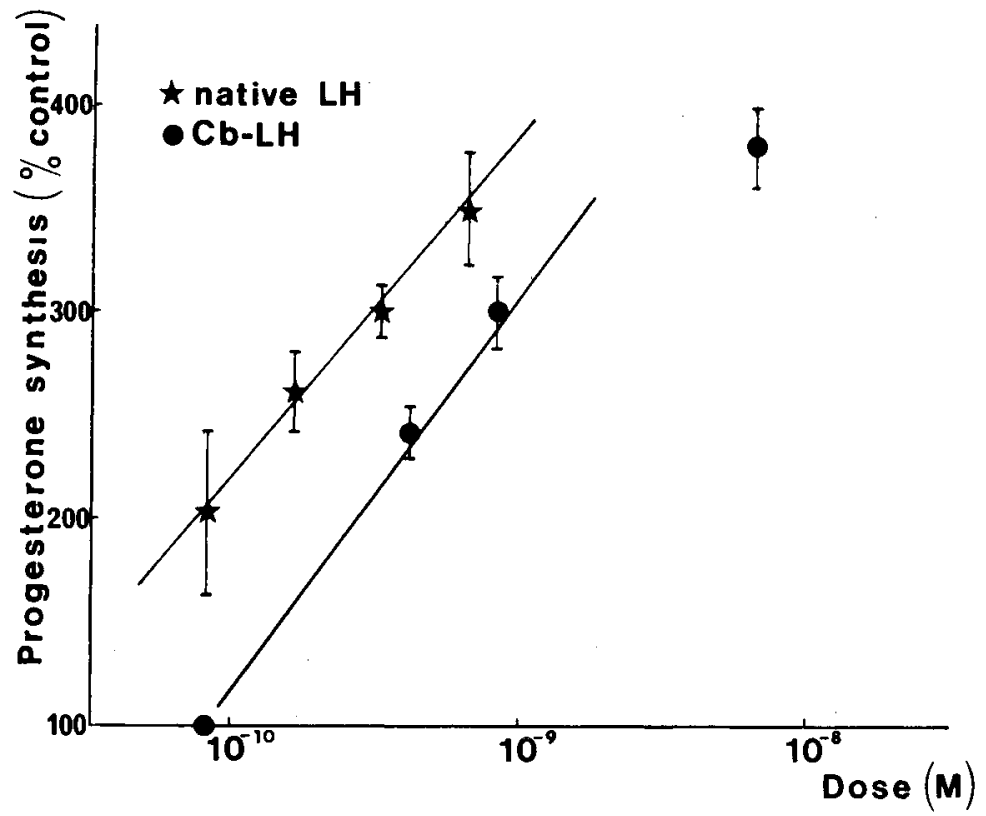

FIG. 3. - Progesterone biosynthesis by pseudopregnant rat ovaries in vitro during incubation for 3 hrs, induced by native $L H$ or carbamylated $L H$. Each point shows the mean \pm SEM ( 2 incubations). Progesterone control : $30.07 \pm 0.75 \mu \mathrm{g} / \mathrm{g}$.

The relative potency calculated with respect to native LH (table 1) shows that a significant loss of biological activity results from carbamylation (about 90 p. 100). The very low residual activity may be explained by a contamination by native LH.

\section{Discussion.}

Good agreement is observed between the biological potencies reported in this paper using the biosynthesis of progesterone as a criterium and those previously 
reported using the ovarian ascorbic acid depletion test. This confirms that the positive charges of one or several residues of lysine are essential for the biological activity (table 2).

TABLE 2

Comparative biological activities of some derivatives of luteinizing hormone $(\mathrm{LH})$

(Relative potencies in terms of native LH)

\begin{tabular}{lccc}
\hline \multicolumn{1}{c}{ Derivatives } & $\begin{array}{c}\text { Progesterone } \\
\text { biosynthesis * }\end{array}$ & $\begin{array}{c}\text { Binding activity } \\
\text { with }{ }^{3} \mathrm{H}-\mathrm{LH} * * \\
\text { De La Llosa-Hermier et al. 1977 }\end{array}$ & $\begin{array}{c}\text { Ovarian ascorbic acid } \\
\text { depletion test } \\
\text { De La Llosa et al. 1974 }\end{array}$ \\
\hline Methylated .... $1.00(0.88-1.14)$ & $0.97 \pm 0.025$ & $1.43(1.01-2.02)$ \\
Guanidinated .. & $0.51(0.39-0.67)$ & $0.315 \pm 0,065$ & $0.55(0.29-1.04)$ \\
Carbamylated & $0.15(0.05-0.43)$ & $0.005 \pm 0.007$ & $0.06(0.01-0.30)$ \\
\hline
\end{tabular}

* See table 1

** Calculated by comparison of the hormone concentration needed for 50 p. 100 inhibition of specific binding in bovine corpora lutea homogenate (means $\pm S E M$ ).

Carbamylated derivatives (abolition of the positive charges) are inactive in all bioassays employed to date, including radioligand receptor assays (Liu et al., 1974, De La Llosa-Hermier ef al., 1977) and stimulation of rat ovarian adenylate cyclase (Tertrin-Clary and De La Llosa, 1975).

The guanidinated derivative exhibits diminished activity. The derivative used in this paper was incompletely guanidinated (65 p. 100 of modified lysine) to permit comparison with the carbamyl derivative. In the radioligand receptor assay using ${ }^{3} \mathrm{H}$-LH, we have obtained about 35 p. 100 of activity (in terms of native LH) for the same guanidinated LH (De La Llosa-Hermier et al., 1977). According to Liu ef al. (1975) a complete guanidination (98 p. 100) leads to an almost total loss of biological activity both in the OAAD bioassay and in the radioligand receptor assay. The decreased activity of these derivatives may be due to steric hindrance resulting from the larger guanidyl groups.

Methylated luteinizing hormone, a derivative with the amino group substituted, but without significant change of the $\mathrm{PK}$ of this basic group, exhibits the same biological activities as native LH (progesterone biosynthesis and radioligand receptor assay with ${ }^{3} \mathrm{H}$-LH see table 2 ). In vivo (ovarian ascorbic acid depletion) methylated $\mathrm{LH}$ is more active than native $\mathrm{LH}$. It must be pointed out first, however, that the clearance rate may be different for the native LH and the derivative, and second that between the ovarian ascorbic acid depletion and the steroidogenesis there may not be a strict linear correlation.

Reçu en jonvier 1977.

Accepté en avril 1977.

Acknowledgments. - This study was done with financial aid from the DGRST, Contract No 74-7-0580. 
Résumé. L'effet de différentes modifications chimiques des résidus lysines de la LH sur la synthèse de progestérone stimulée in vitro par cette hormone dans l'ovaire de la ratte pseudo-gestante a été étudié :

- la carbamylation de 50 p. 100 des lysines (avec perte des charges positives) est suffisante pour provoquer 90 p. 100 de perte d'activité biologique.

55 p. 100.

- la guanidylation de 65 p. 100 des lysines entraîne une perte d'activité d'environ

- la méthylation de 75 p. 100 des lysines ne modifie pas l'activité biologique.

\section{References}

DE LA LLOSA P., DUROSAY M., TERTRIN-CLARY C., JUTISZ M., 1974. Chemical modification of lysine residues in ovine luteinizing hormone. Effect on biological activity. Biochim. biophys. Acto, 342, 97-104.

DE LA LLOSA-HERMIER M. P., HERMIER C., DE LA LLOSA P., 1976. Binding of tritiated methylated luteinizing hormone to bovine corpus luteum receptors. Acta endocrinol., 83, 393-401.

DE LA LLOSA-HERMIER M. P., DE LA LLOSA P., HERMIER C., 1977. Studies of the binding activity to different gonadal receptors of ovine luteinizing hormone (LH) after chemical modification of lysine residues. Gen. comp. Endocrinol, 31, 302-306.

HERMIER C., JUSTISZ M., 1968. Dosage de l'hormone luteinisante (LH) fondé sur son action in vitro dans la biosynthèse de la progesterone. C. R. Acad. Sci. Paris, Série D, 266, 242-245.

JUTISZ M., COURTE C., 1968. Hormone luteinisante (LH) de mouton I. Obtention à l'état apparemment homogène. Etude physico-chimique ef biologique. Gen. comp. Endocrinol., 11, 562-574.

LIU W. K., YANG K. P., NAKAGAWA Y., WARD D. N., 1974. The role of the amino group in subunit association and receptor site interaction for ovine luteinizing hormone as studied by acylation. J. biol. Chem. 249, 5544-5550.

LIU W. K., ESFAHANI M., WARD D. N., 1975. Guanidination of ovine luteinizing hormone and effects on activity. Endocrine Res. Commun., 2, 47-63.

PARLOW A. F., 1961. Bioassay of pituitary luteinizing hormone by depletion of ovarian ascorbic acid, 300-310. In ALBERT A., Human pituitary gonadotropins, Thomas, Springfield (III.).

TERTRIN-CLARY C., DE LA LLOSA P., 1976. Stimulation of rat ovary adenylate cyclase by different LH derivatives obtained by modification of the lysine residues. V. Infer. Congr. Endocrinology, Hambourg, 18-24 July, no 861.

WATSON J., 1971. Progesterone synthesis in response to luteinizing hormone by rat ovarian tissue in vitro. J. Endocrinol., 49, 471-478. 